\title{
Mario Bellatin y la aparición de la imagen*
}

Mario Bellatin and the Appearance of Image

Leo Cherri ${ }^{\text {a }}$

DOI: https://doi.org/10.11144/Javeriana.cl24.mbai

Universidad Nacional de Tres de Febrero, Argentina

lcherri@untref.edu.ar

Recibido: 04 Diciembre 2019

Aceptado: 20 Abril 2020

Publicado: 28 Diciembre 2020

\section{Resumen:}

Este trabajo propone estudiar las acciones plásticas del escritor Mario Bellatin, en lo que respecta al uso de fotografías e imágenes en sus libros, por ejemplo, en Shiki Nagaoka: una nariz de ficción(2001), Jacobo el mutante (2002), Perros héroes (2003), Los fantasmas del masajista (2009) y Biografía ilustrada de Mishima (2009). Sin embargo, la indagación de este fenómeno se detendrá en un momento de su producción relativamente corto (2000-2003), en el cual no solo se constata la aparición de la imagen fotográfica, sino, con esta última, un conjunto de interrogaciones que — sostenemos- implican un punto de inflexión en el sistema creativo de Bellatin.

Palabras clave: Mario Bellatin, imagen-literatura, fotografía, literatura latinoamericana, literatura contemporánea.

\section{Abstract:}

This work aims to study the visual actions of the writer Mario Bellatin regarding the use of images and photographs in his books, for example, in Shiki Nagaoka: una nariz de ficción (2001), Jacobo el mutante (2002), Perros héroes (2003), Los fantasmas del masajista (2009), and Biografía ilustrada de Mishima (2009). Therefore, the investigation of this phenomenon will focus in a relatively short period of production (2000-2003), in which not only the appearance of the image is observed but rather, with the latter, a set of interrogations that —we hold - imply a turning point in Bellatin's creative system.

Keywords: Mario Bellatin, image-literature, photography, Latin American literature, contemporary literature.

[...] para ellos, la vida no es más que un breve tránsito y la nada vence al mundo. Jean-Marie Gustave Le Clézio

\section{Introducción}

Desde Mujeres de Sal, su primera novela publicada en 1986, la escritura de Mario Bellatin ha hecho aparecer la imagen en situaciones que la interrogan y que experimentan con ella. Los modos de esa aparición son diversos. Sin embargo, en ese conjunto rizomático se vuelven insoslayables algunos núcleos problemáticos particularmente densos, que este trabajo se propone distinguir. Para eso, se indagarán las vinculaciones entre escritura, literatura e imagen, ralentizando el análisis en ciertos momentos de la producción de Bellatin en los que, junto con la aparición de la fotografía, se formulan un conjunto de interrogaciones que implican un punto de inflexión en su sistema creativo.

Notas de autor

a Autor de correspondencia. Correo electrónico: 1cherri@untref.edu.ar 


\section{Fotografía e imaginación}

En la obra publicada de Mario Bellatin, la aparición de fotografías en sus libros data del año 2001. ${ }^{1}$ El libro en cuestión es Shiki Nagaoka: una nariz de ficción. Se trata de una suerte de biografía o comentario que relata la vida y obra de Shiki Nagaoka, un ignoto escritor japonés cuya "nariz descomunal, hizo que fuera considerado por muchos un personaje de ficción” (Obra reunida 231). A continuación, voy a resumir el texto in extenso, pues es necesario para los fines de este trabajo.

Entre sus diez y veinte años de edad, siguiendo algunos "preceptos clásicos", Shiki Nagaoka "creó cerca de ochocientos monogatarutsis" o "relatos cortos" (Obra reunida 216). Unos estaban dedicados a "describir las dimensiones del apéndice" y otros a explorar las distorsiones tanto del "olfato" como de "la capacidad de respirar" (216). Luego de aprender una cantidad incierta de lenguas extranjeras "en un período relativamente corto", Shiki publica el Tratado de la lengua vigilada, ensayo donde afirma que "solo trasladando los relatos de una caligrafía occidental a ideogramas tradicionales, es posible conocer las verdaderas posibilidades artísticas de cualquier obra" (216). Es decir, únicamente en la traducción se encontraría la "real esencia de lo literario" (216).

Luego de ser humillado por su sirviente y amante deforme, Shiki se recluye en el monasterio de Ikeno-wo en busca de una experiencia metafísica del lenguaje, buscando un "segundo nacimiento" (217). Allí, arrebatado por un trance místico, al prenderle fuego sus manuscritos e incendiar los bosques del monasterio, acaba comprobando el carácter profético del lenguaje, pues "el fuego se había originado a causa de la pasión que había puesto en sus oraciones" (220).

Antes, durante y después de estos sucesos, el texto va narrando la fascinación de Shiki por el registro fotográfico, pues "consideraba un privilegio contar con imágenes visuales enteras que, de algún modo, reproducían al instante lo que las palabras y los ideogramas tardaban tanto en representar” (217). Sin embargo, al comprobar que "algo tan misterioso y poseedor de tantas potencialidades narrativas se hubiera convertido en una afición de uso doméstico" (218), Shiki acaba poniendo un negocio de revelado. Tanizaki Junichiro es su cliente principal, pues sus fotos, que "retratan una infinidad de cuartos de baños", muestran a la fotografía como "un elemento de manipulación de la realidad" (224). Influenciado por estas ideas de Junichiro, Shiki publica Fotos y palabras, un libro que le dará la vuelta al mundo y tendrá en América Latina una importancia insoslayable. Especialmente, en el trabajo de Juan Rulfo y de José María Arguedas: escritores "fragmentarios" y "mínimos" que, deslumbrados por la imagen, mueren buscando realizar una obra totalizante.

Shiki fue asesinado en 1970, en medio de ese clima de internacionalización de su obra, por unos drogadictos que intentaron robarle las ganancias de su tienda de "revelado fotográfico". Sin embargo, en "sus años finales, Shiki Nagaoka escribió un libro que para muchos es fundamental. Lamentablemente no existe en ninguna lengua conocida" (Obra reunida 228). Según Etsuko, la hermana, Shiki dijo que se trataba de "un bello ensayo sobre las relaciones entre la escritura y los defectos físicos, y sobre cómo la literatura que de allí surge debe distanciarse de la realidad apelando al lenguaje, en este caso al no-lenguaje" (Obra reunida 233).

El desarrollo del relato, bien mirado, parece una suerte de excusa o coartada que acaba narrando en realidad otro relato: el de la literatura y sus instituciones. Ese conjunto de elementos, procedimientos e ideas artísticas termina componiendo no tanto un mero programa o ars poetica, sino, más bien, un campo de fuerzas bipolares. ${ }^{2}$ El relato va y viene de la superabundancia al minimalismo, del tema a la letra, del carnaval referencial de la nariz a lo neutro de la no-referencia, de Oriente a América Latina, de la literatura al misticismo, de la escritura a la traducción y de la imagen al no-lenguaje.

Esta situación del relato es un aspecto que está presente en todos los textos de Bellatin: el giro en torno a una multiplicidad de relatos que lo preceden (Ruiz 203). ${ }^{3}$ En el caso de Shiki Nagaoka, desde su epígrafe ya se envía al lector a un texto anónimo del siglo XIII titulado La nariz y a un cuento de Akutagawa de idéntico 
título (en la primera edición de Sudamericana y en la edición de la Pontificia Universidad Católica del Perú se incluyeron los textos completos directamente al final del libro, bajo el título "Dos narraciones clásicas sobre el tema de la nariz"). A lo largo del texto, también contamos con el relato de la hermana de Shiki (protectora y editora de los manuscritos) y con el rumor, apreciable en fórmulas como "se dice que", "se sabe que", "se comenta que", "no se ha esclarecido si". De modo más abstracto, una serie de nombres (de autores, de películas, de textos literarios y críticos e, incluso, de conceptos) contagian la ficción con los relatos de la crítica o del comentario literario y, a la inversa, en la medida en la que la ficción no solo se resiste, sino que funciona, las instituciones literarias y sus prácticas exponen la ficción que tienen por fuerza. De ese modo, la vida y obra de Shiki - ese relato- se presenta como una deriva que rodea y es rodeada. Y, en ese movimiento, establece una suerte de indiferencia entre vida y obra, literatura y biografía.

Sobre el final del libro se consignan los textos de Shiki Nagaoka sin fecha ni editorial: Monogatarutsis de juventud, Tratado de la lengua vigilada, Fotos y palabras, Diario póstumo y, el impronunciable e intraducible, que no por eso deja de ser editado y, suponemos, leído. Del mismo modo, bajo el título de "Algunas obras sobre el autor", se consigna la bibliografía crítica sobre Shiki Nagaoka: "Conclusiones del I Seminario de Nagaokistas. París, 1999; / KEENE, Donald. Literatura japonesa de posguerra; / NAGAOKA, Etsuko. Shiki Nagaoka: el escritor pegado a una nariz; / SOLER FROST, Pablo. Posible interpretación de "." (Obra reunida 235).

Por último, el libro nos entrega los "Documentos fotográficos sobre Shiki Nagaoka" presentados como una "Recuperación iconográfica" a cargo de Ximena Berecochea: sus padres, sus escritos, mapas, dibujos, los utensilios para limpiar su nariz grasienta. Se tratan de fotos en blanco y negro en las que se instaura una resistencia visual, por ejemplo: "Graduados de la quinta promoción de la escuela de lenguas extranjeras Lord Byron, donde Shiki Nagaoka fue uno de los más destacados alumnos. Nótese el círculo” (figura 1). El efecto, esto no puede ser menos irónico: como vemos, dentro de ese círculo que alguien trazó estaría nada menos que un rostro. En la fotografía, esa singularidad se presenta desgastada (¿ por el tiempo?) y el montaje, al señalar, no demarca un punto de reconocimiento, sino, por el contrario, un gesto indicial: lo que notamos no es ningún rostro, sino, justamente, su señalamiento. Así las cosas, el lenguaje renueva las relaciones de extrañamiento, pues "esta" y no otra es la situación del alumno destacado: no él (sus características físicas o mentales), ni tampoco su rostro (aquello que exterioriza singularmente su interioridad en una superficie), sino el círculo que lo demarca en una foto. 


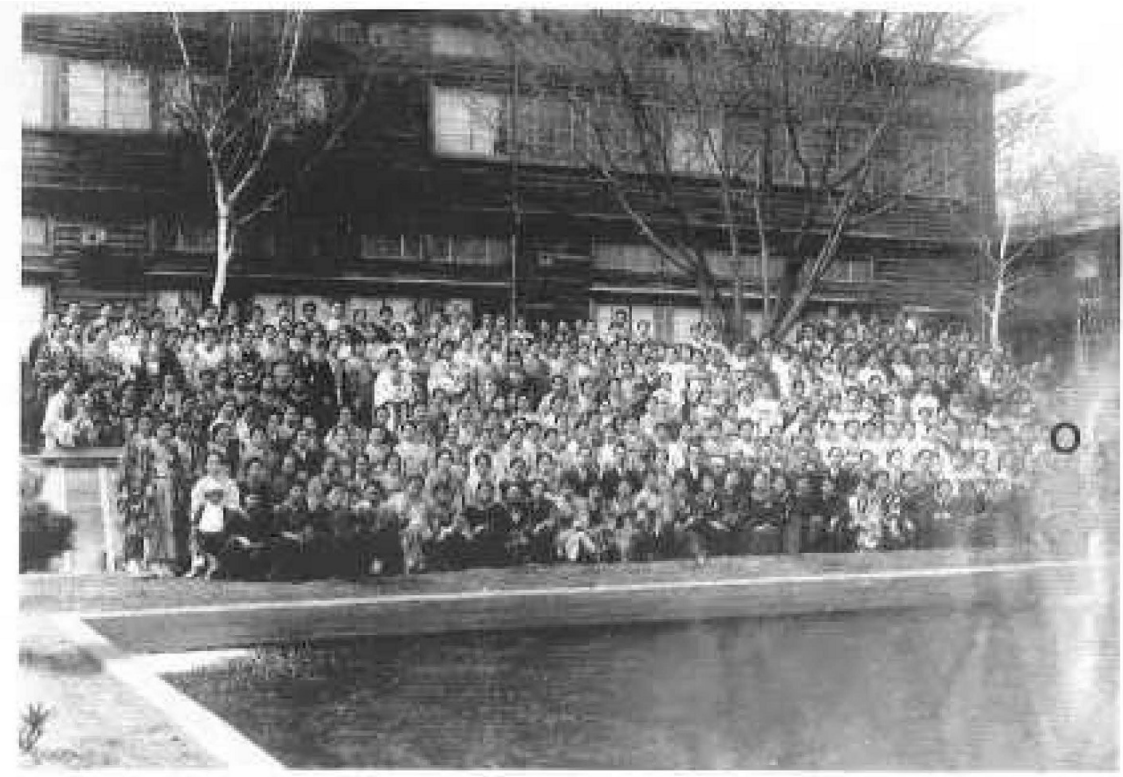

Graduacion de la quinta promorion de la estula de lenguas extranjeras Lord Byron donde Nagaoku Shiki jur uno de los mis destacados alumnos. Nötese el circulo.

Mongatawisis de jumburd.

FIGURA 1 .

Foto de graduación: "Graduación de la quinta promoción de la escuela de lenguas extranjeras Lord Byron, donde Shiki Nagaoka fue uno de los más destacados alumnos. Nótese el círculo” Fuente: Bellatin, Obra reunida (237)

Es esto lo que en Shiki Nagaoka se estaría aclarando al pie de la imagen: el señalamiento, no de qué es lo que vemos - puesto que el maltrato de las imágenes a veces nos muestra puras opacidades-, sino aquello que ha sido y que, sin embargo, no sabemos lo que fue ni lo que es. Lo intratable de la fotografía, dice Roland Barthes, es ese interfuit: "Lo que veo se ha encontrado alli", pero "ha sido inmediatamente separado", ha estado "absolutamente presente" y, sin embargo, "diferido ya", y ese lugar "se extiende entre el infinito y el sujeto" (136-137). Pero esta extensión que desplegaría un espacio cualquiera no se trata de un "universal abstracto, en todo tiempo, en todo lugar", sino de una singularidad "que ha perdido su homogeneidad", sus "relaciones métricas": ese rostro opaco que hace notar al círculo que lo distingue. Lo cualquiera instaura una "conjunción virtual", un "puro lugar de lo posible". Es, entonces, la aplicación de una inestabilidad a la imagen lo que despliega una "riqueza de potenciales [...] que son las condiciones previas a toda actualización" (Deleuze 160-161).

En este punto, se produce una suerte de saturación del juego entre ficción y biografía. Por un lado, los "epígrafes" se encuentran a la sazón de parodiar burlonamente el uso biográfico o periodístico de la fotografía, es decir, aquella expectativa documental que la fotografía no puede saldar, sino recurriendo al lenguaje: "Esto (visual) es esto (verbal)". Es decir, el precio de mostrar(se) se paga con la imposibilidad de decir(se) y viceversa: no un dilema, sino una bipolaridad.[4] Podríamos decir junto con Alan Pauls que se trata de una "histeria fría", siempre y cuando acotemos, ya que su posicionamiento se presta a malentendidos (Walker 3), que esa relación entre lo visible y lo legible no es esencial o sintética, ni, muchos menos, dialéctica. Es, más bien, analógica, pues los efectos de la tensión entre lo visible y lo legible no corresponden dicotómicamente a las imágenes, por un lado, y a los nombres, por el otro, sino a la analogía bipolar que los distingue y desdiferencia. 
En ese sentido, es la irrupción del lenguaje al pie de la fotografía lo que extrapola la inestabilidad de las imágenes, instaurando una suerte de roce absurdo que hace delirar el registro fotográfico, llevándolo a su plano de inmanencia: lo in-fotografiable.

Se concluye, entonces, que la operación paródica es fundamentalmente creativa: si la "documentación iconográfica” opera sobre lo ridículo de la mostración biográfica, en tanto que prueba de la existencia de lo existente, es sobre esa pretensión de algún tipo de verdad que Bellatin, además de demostrar la irrealidad propia de cualquier registro, acaba por construir una prueba de la existencia de lo inexistente. Por consiguiente, la fotografía se vuelve un campo agujereado que solo puede atravesarse vía la imaginación, por medio de la escritura.

Una sola imagen, indica Georges Didi-Huberman, es capaz de reunir todo esto y "debe ser entendida por turnos como documento y como objeto de sueño, obra y objeto de paso, monumento y objeto de montaje, no-saber y objeto de ciencia" (10). La primera "iconografía", por ejemplo, muestra a los "padres de Shiki Nagaoka" e indica: "Nótese la modernidad de costumbres, evidenciada en los guantes y lentes de Zenchi Fukuda y en el uso de lápiz labial de Zenchi Zachiko, lo que de algún modo demuestra su pertenencia a la clase aristocrática" (s. p.). En otras palabras, la Historia de una fotografía (de los tejidos, de las modas, de las culturas, de los adornos, es decir, lo que en Shiki Nagaoka podría responder al nombre de "lo oriental" o "lo exótico") se vuelve permeable, en mayor o menor medida, por este efecto de verdad que pretende crear un nuevo orden (imaginario), donde la realidad de su ha sido es actualizada sin perder por eso un resto aurático que subsiste, persiste, frente a nosotros: aquella imagen, por más agujereada que se nos presente, no deja de ser una fotografía y, fundamentalmente, la fotografía de un rostro (figura 2). Ejemplar al respecto es la "Fotografía de Shiki Nagaoka manipulada por su hermana Etsuko, con el fin de evitar que el autor fuera considerado un personaje de ficción" (Bellatin, Shiki 253). 


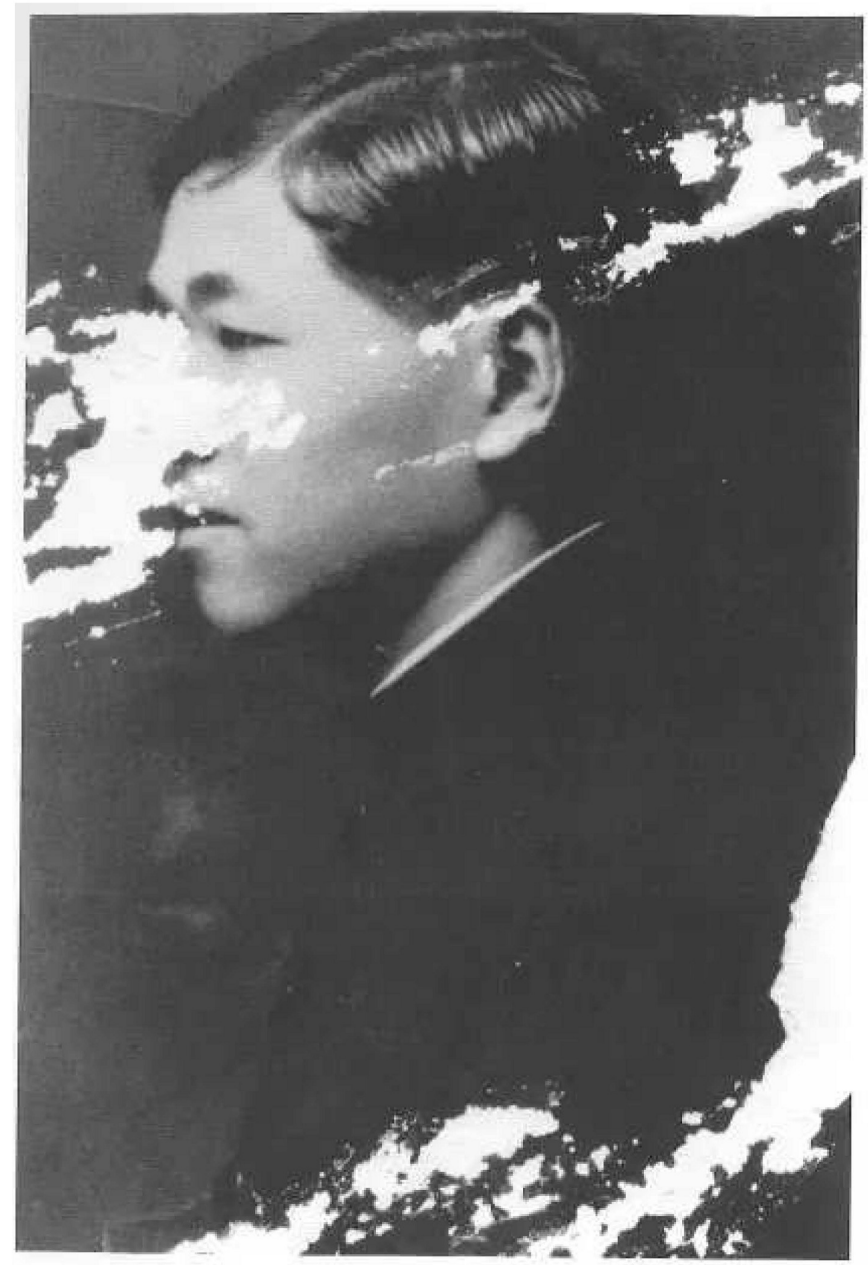

Fotografia de Nagaoka Shiki manipulada por su bermana, Etsuko, con el fint de evitar que el autor fuera considerado un personaje de fición.

FIGURA 2.

Fotografía de perfil: "Fotografía de Shiki Nagaoka manipulada por su hermana Etsuko, con el fin de evitar que el autor fuera considerado un personaje de ficción” Fuente: Bellatin, Shiki (253)

\section{Sobre-exposición y des-creación: la nariz y el no-lenguaje}

Volvamos, entonces, al comienzo del texto: "Lo extraño del físico de Nagaoka Shiki, evidenciado en la presencia de una nariz descomunal, hizo que fuera considerado por muchos como un personaje de ficción" (Obra reunida 215). Promediando la mitad del relato, se nos dice que el verdadero nombre de Shiki es "Naigu Zenchi" (218), el mismo nombre del personaje de Akutagawa. Y, al final, se nos presenta la fotografía del rostro de un ser de ficción. Sin embargo, allí donde algún tipo de verdad debería ofrecerse a la vista (las fotos de perfil, se supone, nos muestran perfiles), se produce una operación táctil (una rasgadura) cuyo efecto (el confinamiento visual de la nariz) evitaría que el autor acabe siendo un personaje de ficción. La paradoja es evidente y es doble: es el montaje (la rasgadura) lo que salvaría a Shiki (ese apéndice enorme y grasiento) de las garras de la ficción; sin embargo, en la medida en que se ejecuta esa operación se define no solo el régimen o condición de posibilidad de la ficción, sino de lo real. En otras palabras, ya "no se trata entonces de que la 
verdad tenga estructura de ficción", sino "de algo mucho más grave (quiero decir: de mayor alcance y de mayor contradicción): a lo real hay que imaginárselo" (Link, Fantasmas 119; cursivas en el original).

Es ejemplar al respecto el inicio de la narración de Akutagawa:

No hay nadie, en todo Ike-no-wo, que no conozca la nariz de Zenchi Naigu. Medirá unos 16 centímetros, y es como un colgajo que desciende hasta más abajo del mentón. Es de grosor parejo desde el comienzo al fin; en una palabra, una cosa larga, con aspecto de embutido, que le cae desde el centro de la cara. (Bellatin, "Dos narraciones" 85)

En ese sentido, el rasgado no es solo una propiedad del montaje fotográfico, pues, si consideramos a Shiki Nagaoka como una operación sobre el texto de Akutagawa, esta se basa no tanto en reformular, sino en agujerear ciertos campos, vaciar puntos, cortar el lenguaje, es decir, propiciar una inestabilidad en las relaciones métricas con el fin de generar esa fuerza de misterio que impulsa al relato.

Ver los cuerpos, explica Jean-Luc Nancy, "no es develar un misterio, es ver lo que se ofrece a la vista", una imagen que " es extranjera a toda imaginación, a toda apariencia - y del mismo modo, a toda interpretación, a todo desciframiento-” (46; traducción propia). Pero, en nuestro caso, la nariz no se ofrece a la vista e, incluso, no es tanto "la nariz" aquello que se resiste, sino su tamaño. Lo que en el conjunto de elementos orientales se vuelve exótico-extraño para lo exótico-extraño. ¿Pero, si ya hay una operación de extrañamiento de lo extraño, cuál es el sentido de confinar al vacío este particular visible? La nariz, su tamaño, se presenta como una ostentación y una complicidad con lo visible que, aunque no supone un enigma por resolver, produce un misterio - una ocultación insoslayable - que la envuelve en su extensión: al instaurar un exceso nominal y métrico en torno al apéndice, las operaciones de montaje potencian sus sentidos. Vía la nariz, el cuerpo de la ficción y la imagen del autor se envuelven en un misterio vitalista de mutuo engendramiento y deceso, cuya diferencia se aprecia en la variación mínima del montaje. $\mathrm{Si}$, como dijimos, la fotografía del rostro nos trae a colación la cuestión del aura, cuando esa singularidad es, además, la imagen de un autor, surge la problemática del fetichismo artístico. En estos términos, el confinamiento visual de la nariz adquiere unos sentidos específicos.

$\mathrm{Al}$ respecto, conviene recuperar la célebre asociación psicoanalítica que hace Freud en su artículo "Fetichismo" de 1927. Es el "brillo sobre la nariz" - Glanz auf der Nase en alemán_ lo que atrae a un determinado paciente cada vez que lo descubre en ciertas mujeres. La lengua materna y olvidada del paciente era el inglés: el brillo, es decir, el Glance, es una mirada. Y Freud, él lo admite, apresura la interpretación: para cada sujeto, el fetiche es algo específico, pero, a la vez, es siempre lo mismo: un sustituto del pene; no uno cualquiera, sino uno particular, el falo de la madre (161-162).

Es decir, si Freud se apresura es porque el falo materno, en el diagrama de la castración, le viene como anillo al dedo. Sin embargo, ese doble régimen del fetiche señala algo más: que cualquier objeto pueda ser virtualmente un fetiche termina por minar la presuposición de una ur-forma u objeto-tipo. Si "el pene no tiene forma de pene 'entonces tal vez una época obsesionada con la necesidad de castración ha alcanzado su ocaso'” (Echevarren 25). ¿Tal razón explica que Freud no insista en la otra asociación significante, igualmente latente, la del alemán Glanz con el inglés Glans, es decir, el glande? Ese devaneo leve (glanz, glance, glans), lejos de tipificar el objeto fetichista, estaría señalando un diagrama diferente, uno que lo presenta como un vacío constitutivo: el fetiche es un objeto, si se quiere, pero confinado a ese infinito que el psicoanálisis llama desplazamiento y el arte pop llama serie.

Lacan, recuerda Daniel Link en Suturas (178), postuló en 1958 al "falo como significante de la razón del deseo (en la acepción en que el término es empleado como 'media y extrema razón' de la división armónica)”. Posteriormente, el 19 de abril de 1967 en el Seminario XIV sobre La lógica del fantasma, Lacan explica que el número de oro ("nombre d'or") es aquel que "para llegar a un cierto límite de aproximación, demanda todas las formas — son múltiples y casi infinitas— de lo inconmensurable, [...] demanda el máximo de operaciones” (9). Por eso, "estas operaciones no se detendrán ni terminarán jamás" (10). 
Es decir, el objeto-a y la razón aurea entran en una relación de semejanza que otorga soporte y función simbólica como densidad al deseo que, se nos dice, no tiene término. Aunque, como señala Link, "tal vez no convenga tomarse tan en serio los chistosos argumentos" del "Dr. Lacan" (Suturas 178). De cualquier modo, ya que estamos interrogando sobre la nariz y su tamaño, no podemos obviar la seriedad, por más chistosa que resulte, de tales signaturas: lo inconmensurable y la serie infinita. Lo que equivale, en nuestro caso, al montaje del rasgado y a la (re)escritura como corte.

Por otro lado, lo que conviene tomarse en serio, aunque ahora sí se trate de un chistoso experimento realizado a cierta Sociedad de Artistas Independientes (Nueva York) es, en el texto de Link, el salto epistémico sobre el centro del cuerpo que produjo el "mingitorio puesto en perspectiva" (Suturas 173) de Marcel Duchamp firmado por R. Mutt que hace "todo lo contrario" de la semejanza clásica, pues impugna "toda noción de centro, al situar metonímicamente el problema de la divina proporción (de la verga) fuera de cuadro: un centro ausente en su lugar" (175). ${ }^{6}$ The Fountain (1917) "cita solo por metonimia o vacío aquello que durante siglos constituyó, al mismo tiempo, el centro de la soberanía y el centro (naturalmente, heteronormativo) de los cuerpos". Lo que funda ese ready-made es un cuerpo nuevo que "falta en su lugar. Para decirlo con Nancy, un cuerpo áfalo, acéfalo, inorgánico" (Link, Suturas 179). Lo “mismo" podríamos leer en un rostro opaco señalado por un círculo (acéfalo), en una foto de perfil rasgada (áfalo) y, por consiguiente, en la des-obra signada por la reescritura y el montaje (inorgánico).

En este punto, la polémica del mingitorio nos exige retomar la cuestión del fetichismo, pues, como sabemos, la Sociedad de Artistas Independientes rechazó, no la obra de Duchamp, sino la obra de R. Mutt. Ese rechazo no es menor, pues, en cierto punto, constata el paradigma fetichista del nombre del autor que, al presentarse al igual que el apéndice en su ausencia (pues R. Mutt no designaba a persona alguna), devaluó hasta el grado cero la exposición de la obra. No fue un desacierto de André Breton, sino una receptividad epocal lo que llevó a definir al ready-made vía la soberanía de la elección del artista, que mediante su firma y una operación nominalista dotaba al objeto de estatuto artístico. Tampoco se equivocaba el dadaísmo, que, al realzar el valor de culto del artista, generalmente de modo abyecto, lo volvía una suerte de rey Midas que convertía a los objetos no en oro, sino en "obra de arte".

Esta cuestión se presenta en varias iconografías de Shiki. De ese modo, vemos-leemos el "cuenco que contenía el agua hervida necesaria para el tratamiento de la nariz", el "exprimidor de nariz", el "vaso preparado para recibir la grasa eliminada por medio del tratamiento", el "espejo que usó Shiki Nagaoka para apreciar los resultados experimentados en su nariz", la "vajilla que utilizó Shiki Nagaoka en la casa donde pasó sus últimos años", el "calzado que el autor se colocó a diario para ir a trabajar al kiosco fotográfico”, etc. Sea lo escatológico (la nariz grasienta) o lo anodino (el calzado diario) lo que se señala no es otra cosa que el carácter fetichista de esa puesta en escena de la inexistencia. Y es este punto, la fetichización de lo inexistente o ausente, lo que permite reapreciar críticamente la operación.

En 1961, Piero Manzoni presentó sus noventa latas de Merda d'artista, haciendo equivaler el gramo de mierda al de oro. Allí, más allá de la relación entre mierda y oro, como también entre analidad y arte, se produce una deriva del cuerpo del artista hasta sus desechos, que, paradójicamente, se encuentran "enlatados". Ese circuito productivo pone al arte y a la autofiguración del artista en una situación de confinamiento: un vacío visual en el que la posibilidad de ver se encuentra, cual tragedia placentaria y sinestésica, al alcance de la mano. Esa tragedia ya se había presentado antes en Fiato d'artista, donde lo que es dado, en este caso el aliento, se encuentra contenido por globos. De ese modo, lo somático, sea del orden del desecho (el artista como máquina excrementaría) o del orden de la posibilidad productiva (el artista como máquina deseante), es sometido a un orden preverbal (la lata, el globo, el huevo, la placenta) y, por eso mismo, a un régimen de visualidad confinada (un vacío visual que apela a otro tipo de contacto sensible).

De ese modo, podríamos pensar la fetichización del autor en la iconografía de Shiki Nagaoka (esa sobreexhibición) como una producción de efectos paradójicos, pues, al igual que los objetos de Manzoni, genera "frustración deliberada de nuestra sensación visual", lo que podría leerse como una "estrategia de resistencia 
contra la conversión de la cultura [y el arte] en espectáculo" (Foster et al. 414). Es, como vemos, un movimiento doble que articula nominalmente una sobre-exposición de algo que no deja verse, pero que resiste, presente, bajo la forma del vacío pre-nominal (una des-creación). Esa frustración, somática y preverbal, cuyo régimen es abyecto-deseante se expresa en otra iconografía, cuyo epígrafe reza: "Símbolo con el que se conoce el libro intraducible de Shiki Nagaoka" (Obra reunida s. p.)

El libro impronunciable e intraducible - que no por eso deja de ser leído, editado e interpretado, pues cuenta incluso ¡con bibliografía crítica! - se presenta como la pura materialidad sin contenido. Es imagen (pues expone la visualidad de un cuerpo que piensa), pero, a la vez, es letra (pues se trata de un significante que, aunque no estaría desprovisto de significado, se expresa directamente en su no-pensamiento). Sin embargo, ni el relato ni la fotografía resuelven una incertidumbre crucial, al contrario, la acentúan: ¿el símbolo es meramente un título - operativo, pues el libro carece de todo nombre- o es, nada más y nada menos, que el libro mismo? De cualquier modo, esa letra sin-lenguaje o lenguaje pre-verbal envía, en efecto, a las inscripciones pre-históricas.

En este punto, es preciso recordar, por ejemplo, el kohau rongorongo: esas misteriosas inscripciones en tablas de madera halladas en la Isla de Pascua. El caso es célebre para la etnografía, pues, para las corrientes funcionalistas, se trataba del "descubrimiento" de una escritura. Sin embargo, como señaló Raúl Antelo, fue Alfred Métraux en su libro dedicado al tema quien concluyó que

no se trataba, en el caso de esas enigmáticas figuras, de una auténtica escritura y por lo tanto del umbral de la historia para esa cultura, sino de simples fórmulas mnemotécnicas que recién mas tarde adquirirían valor sagrado para sus usuarios. Métraux llegaba a ese convencimiento porque, a la manera mimológica de Mallarme, leía tales inscripciones a partir de una muy precisa concepción del lenguaje, la de un puro espacio de la ficción, y no veía en él un instrumento de comunicación o fundación de comunidad. No hay razón en el lenguaje, hay tan solo juegos de poder. ("El tiempo" 380)

Desde esa óptica, explica Antelo, es el olvido el "auténtico ritual de fundación de una literatura, como si esta buscase, a través de la amnesia, reanudar los vínculos con el improbable origen, y como si la palabra misma no dispusiese de ninguna archè para afianzar sus fundamentes" (380). Desde esa perspectiva, la escritura no sería un remedio contra el olvido, sino contra la memoria. Pero también, ciertamente, un don: la falta de fundamento de una literatura. Así las cosas, el crítico concluye equiparando esta concepción mnemónica que va desde un pueblo que ya no existe, pasando por los poetas modernos, hasta llegar a un antropólogo de avanzada - a las posautonómicas: "Aquello que define la literatura al carecer de un marco fundacional inequívoco es, por el contrario, la infinita oscilación en su inefabilidad. Tales inscripciones son, como diría Ludmer, alidadficción, y otra no es la consistencia paradojal de la máquina mitológica” (380-381).

Esa situación de infinita inefabilidad y de realidadficción no solo está dada en Shiki Nagaoka, como venimos viendo, sino también en su pre-texto creativo. A mediados del año 2000, Bellatin fue invitado al palacio de Bellas Artes a participar de un ciclo de charlas donde cada participante tenía por encargo hablar de su escritor favorito. Como declara en una entrevista del 2008, al cabo de un tiempo de pensar su intervención, advirtió lo obvio: "Que no puede haber un autor preferido, sobre todo porque escoger a uno elimina al resto. Fue por eso que decidí crear mi autor favorito, que creo apareció, sin darme mucha cuenta, como una suerte de alter ego" ( Los Asesinos Tímidos). La intervención, por más seria que parezca, no fue reticente al chiste, puesto que en ningún momento de la jornada la operación fue aclarada y, tiempo después, el escritor llegó a recibir una carta del Departamento de Literaturas Orientales de la Freie Universität de Berlín, pidiéndole información acerca del autor desconocido (Sánchez).

Un autor favorito, entonces, no implicaría una selección sobre un conjunto, sino la construcción de una imagen que, paradójicamente, acaba siendo un alter ego. ¿Bellatin se avergüenza por el hecho de que su autor favorito es su (im)propia imagen y por eso hay ficción? ¿O nos estaría diciendo que lo favorito no podría ser un autor sino el genius de cualquier autor: lo impropio, lo no-consciente sin denegación, ese otro del que se forma parte? ${ }^{8}$ 
En ese sentido, Shiki Nagaoka funciona en la obra de Bellatin como el punto de sutura entre la imagen (la autofiguración de autor) y el lenguaje (de la literatura): por un lado, la situación paradojal de reunir en una obra (un libro, una imagen) la escisión de un sí mismo múltiple que se extiende en su diferencia y, por otro lado, la situación aporética de tener que sostener una escritura cuya lengua le es completamente ajena o ausente. Por eso, es cuanto menos sintomático que la aparición de los elementos orientales (apenas un año antes con El jardín de la señora Murakami) coincidan no solo con la cuestión del autor, sino también con la aparición de la fotografía, esa "extranjera" formal. Cuestión que abordaremos a continuación.

\section{El carácter visual de los nombres}

El jardín de la señora Murakami es una supuesta traducción de un texto titulado Oto no-Murakami monogatari al cual no tenemos acceso y cuyo autor desconocemos. El texto versa sobre la historia de Izu, una estudiante de arte que se ve envuelta en unos conflictos a partir de la publicación de una crítica que le hace a la colección del señor Murakami, quien, posteriormente, se convertirá en su esposo.

Otra vez, el tópico de las instituciones artísticas aparece en todos los niveles. Sin embargo, la particularidad de este texto es la reaparición de los nombres. Después de Mujeres de Sal, ese libro que Bellatin no ha vuelto a editar desde 1986, y a partir de Efecto invernadero en 1992, los personajes comenzaron a carecer de nombres y pasaron a ser designados por roles o según las funciones que desempeñaban en el relato. Así, nos encontramos con una suerte de epítetos que, en vez de calificar y acompañar a los nombres, los remplazan: la protegida, el poeta ciego, nuestra señora, el amante, la amiga, los hermanos, el niño, la mujer, los hijos, etc. Podríamos decir que se trata de una retórica donde las calificaciones sustituirían a las clasificaciones, es decir, al nombre como principio de toda agrupación y colección. Así planteada la cosa, los nombres presentados no identifican, sino que valoran, no ordenan, sino que son pura latencia tanto de un posible orden como de un rotundo caos de sentido. De esta forma, el nombre también atraviesa una suerte de espacio cualquiera.

Esta prohibición nominal de Bellatin — que, dicho sea de paso, también suele afectar a los colores, a los lugares, al tiempo y a los diálogos - no es en modo alguno azarosa, como tampoco se trataría de un acto de creatividad inconsciente o de escritura automática. Es, en realidad, un proceso de censura: en un manuscrito previo de Efecto invernadero titulado "Y si la belleza corrompe a la muerte" podemos ver cómo estos roles originariamente tenían nombre y que, en verdad, eran deformaciones de nombres que estuvieron vinculados a la vida de César Moro. Allí, Graciela Goldchluk explica en una nota al pie: "Los nombres elegidos evocan los biográficos sin utilizarlos, como en el caso de Aubert por André Coyné” (Bellatin, Condición 53).

Este paso de la alusión a la elisión, explica la genetista, es "una construcción típica de este momento de la escritura de Bellatin” y, posteriormente, la elisión "se convertirá en un principio constructivo de su poética, mucho más allá del sistema de nombres" (Bellatin, Condición 53). Aunque, en efecto, la elisión se encuentre "más allá" de cualquier "sistema de nombres", no podemos ignorar que se trató de un proceso de escritura surgido en una situación específica que implicaba insinuar la figura de César Moro sin exponerla. En esa bipolaridad, la elisión fue como el círculo o el mingitorio, pues no acabó distinguiendo cosa o referencia alguna (un rostro, una figura, un apéndice), sino el mismísimo señalamiento, es decir, no el nombre (del padre o del autor), sino los gestos que rodean la escritura que es capaz de producir: "Aquello que permanece inexpresado en todo acto de expresión" (Agamben, Profanaciones 87).

Dice Barthes: "Lo que puedo nombrar no puede realmente punzarme. La incapacidad de nombrar es un buen síntoma de trastorno" (100). Resulta un tanto revelador que Barthes haya definido una de sus categorías fundamentales para pensar la fotografía por medio de un recurso, si el lector lo concede, nominalista. Esta relación entre punctum y nombre bien podría ser una línea interesante de lectura, siempre y cuando comprendamos que en Bellatin no se trata de poder o no nombrar, sino de que aquello que es susceptible de 
ser nombrado ha atravesado un proceso de de-formación o de vaciado, quedando de él una suerte de etiqueta hueca, un link roto, un salto in media res. En ese sentido la imposibilidad del nombre.

Por eso, si en El jardín de la señora Murakami los nombres reaparecen es porque su opacidad ya está doblemente asegurada por la traducción, el anonimato del autor y lo oriental, lo que en realidad —como veremos más adelante- es una misma cosa.

Desde el título, ese espacio infinito se materializa: oto en japonés significa 'sonido', y monogatari, 'historia', 'cuento' o 'relato'. La traducción lata nada tiene que ver con jardines. Se me dirá que una traducción puede tomar esas licencias y muchas más. Sin embargo, tanto las "notas al pie" como la "Adenda" vienen a extenuar dicho procedimiento, remarcando esta posibilidad de lectura: todos los elementos contextuales que deberían poner en relación una cultura con otra, una lengua con otra, un sistema de escritura con otro, acaban transformando la traducción en un disparate. Sea porque la definición de una palabra es ridícula, o porque la "Adenda" contradice la historia o, cuanto menos, se burla de ella.

Por ejemplo, el punto nueve de la "Adenda": "El Terrin de Satusumeri-oto que pide Izu en el salón de té de estilo francés que visita en compañía de Etsuko, parece ser, sencillamente, un pastel con pescado” (Obra reunida 200). Es decir, la desmesura de los elementos contextuales explicativos propios de esta traducción son puestos en ridículo ante la "sencillez" de la cosa. Lo mismo podríamos decir de la definición de kimono, en tanto "traje tradicional confeccionado principalmente por mujeres" (Obra reunida 154).

Esto es a lo que anteriormente aludíamos cuando hablábamos de doble inestabilidad. Por un lado, la traducción dejaría una suerte de lastre de sentido, de vacío constitutivo, que se maximiza en este caso por la diferencia no solo de lengua, sino de sistema de escritura; y, por otro lado, el imaginario japonés, como el judío, el árabe, el imaginario del sida e incluso la imagen del autor, instauran una "falsa retórica", no un punto de llegada, sino un punto de camino, de tránsitos por no-tiempos y no-espacios, conjuntos de elementos que no el autor, sino el lector ha de depositar y manipular. Sería una suerte de exotismo, como el que lee Sandra Contreras en Las vueltas de Cesar Aira, pero expandido: porque no implica ver la nación desde una supuesta otredad (negatividad nietzscheana, tupi or not tupi antropofágico), sino desde la persecución de una experiencia de desterritorialización de los dispositivos, en este caso, de los dispositivos de lenguaje.

Nietzsche lo ha dicho en Aurora (f. 123), y Bellatin lo sabe: detrás de las cosas existe "en absoluto su secreto esencial y sin fechas, sino el secreto de que ellas están sin esencia, o mejor, que su esencia fue construida pieza por pieza a partir de figuras que le eran extrañas". Esa extrañeza que "se encuentra al comienzo histórico de las cosas, no es la identidad aun preservada de su origen — es la discordia de las otras cosas, el disparate" (Foucault $10)$.

Por consiguiente, las palabras explicadas en El jardin de la señora Murakami son llevadas hasta lo más profundo de sí (el disparate) y el delirio del nombre contagia a todos los nombres (a todas las figuras): la escritura funciona también como un no-lenguaje, el nombre es arrastrado a su plano de inmanencia: lo innombrable. Es decir, se vuele pura imagen o voz, no lenguaje: la historia sonora de Murakami.

Por eso, no se trata de que la narrativa sea fotográfica, por su efecto de encuadre o selección, sino, más bien, poética: se produce una transformación entre las palabras y las cosas que no podemos o no importa precisar, sino que conviene, más bien, atravesar. Lo que equivale a un libro escrito en un lenguaje intraducible, o a la traducción de un texto inexistente, o a una foto de lo inexistente rasgada en el clímax de su fetichismo igualmente exotista. Habiendo alcanzado una experiencia de desterritorialización, el efecto es más o menos obvio, el lector experimenta un estado adánico, pero presentado a través una aparente paradoja de sentido: volver a nombrar al mundo, sí, pero plagándolo de imágenes. Esto es, "producir o inventar el aspecto 'visible' de lo que carece de toda visibilidad" como quien "intenta acercar a la visibilidad aquello que, propiamente, sería invisible" (Pardo 543-544).

Ese carácter creativo de la imagen es la interrogación que Shiki Nagaoka: una nariz de ficción le formula a la fotografía, pero que primero El jardín de la señora Murakami se propuso replantear en torno al nombre. 
Deberíamos desconfiar de esta causalidad, pues, a decir verdad, Shiki Nagaoka ya había anunciado tales artimañas de Eljardin:

En su ensayo, Tratado de la lengua vigilada, aparecido tardíamente en el año de 1962 en Fuguya Press, afirma que únicamente por medio de la lectura de textos traducidos puede hacerse evidente la real esencia de lo literario que, de ninguna manera como algunos estudiosos afirman, está en el lenguaje. (Obra reunida 216)

"Fuguya" es el nombre de la editorial que publica este Tratado de la lengua vigilada. En El jardín de la señora Murakami la palabra fuguya puesta en cursivas y con su correspondiente nota al pie designa la "vara tradicional que simboliza el poder de quien la detenta. Antiguamente la usaban los maestros de más alto rango" (Obra reunida 169). Finalmente, en japonés, fuguya es nada. Vuelta una cosa cualquiera, podría ser absolutamente todo: el desafío de la imaginación que supone la masa invisible del universo.?

\section{Las metamorfosis de la materia: el archivo recobrado}

En el 2002, Bellatin publica Jacobo el mutante. La temática literaria persiste: el texto se presenta como una crítica o comentario genetista sobre un texto de Joseph Roth del que se conservan dos manuscritos. La frontera es el texto en cuestión que trata sobre la vida de Jacobo Pliniak, un rabino no reconocido como tal, que, situado en el condado de Korsiakov, colabora con los judíos que huyen de los pogromos rusos. En cierto punto del relato, Jacobo aparecerá en América y sufrirá una mutación. Metamorfoseado en una anciana mujer (Rosa Pliniason, la que antes era su hija adoptiva), intentará combatir el crecimiento desmedido de unas academias de danza.

Este texto también presenta una estructura que incorpora diversos materiales, a la vez que los hace explícitos. En cursiva, distinguimos una serie de fragmentos de lo que sería la supuesta novela de Roth, sin embargo, estos no están citados, sino incrustados en el cuerpo del texto sin nada más que esta diferencia de formato. Por otro lado, tenemos el relato del crítico o comentador, que va trazando una suerte de símil entre la vida de Roth y la de Jacobo, entre las obras de Roth y los dos manuscritos póstumos. Todo mechado por interpretaciones literarias y religiosas relacionadas con la Biblia, la Torá y la cábala. Y, otra vez, las fotografías de Ximena Berecochea.

A diferencia de Shiki Nagaoka, todos estos materiales se presentan uno al lado del otro. Acoplados, deberíamos decir. No hay separación, más que los puntos, los renglones y tres títulos: "La espera", "Beatitudes" y "Sabbath". En semejante concentración, las imágenes parecen funcionar como signos de puntuación. Separando una predicación de otra, un fragmento de otro. O generando una suerte de pausa: una hendija por la cual el texto respira. Y digo esto porque si bien las imágenes (fotos de tierra, pasto, rocas, paja y agua) podrían sugerir cierta relación con algunos paisajes de La frontera (el pantano, el rio, el condado), para ser fotos de paisajes la cercanía de los planos, antes que construir un lugar más o menos difuso, maximiza la textura de los elementos (figura 3). Ya lo señaló Marcelo Díaz en Bazar Americano: "Las fotografías, en efecto, no ilustran, más bien arman una suerte de discurso paralelo en donde se despliega un misterio: hay fronteras, orillas, pasajes de lo sólido a lo líquido, de lo mineral a lo vegetal, de lo vegetal a lo animal". 
gua esposa. Ha sido abandonada por el joven Anselm, y tiene una hija llamada Rosa. La mujer realiza trabajos menores para gente de la comunidad, pero vive prácticamente de la caridad pública. Jacobo se apiada

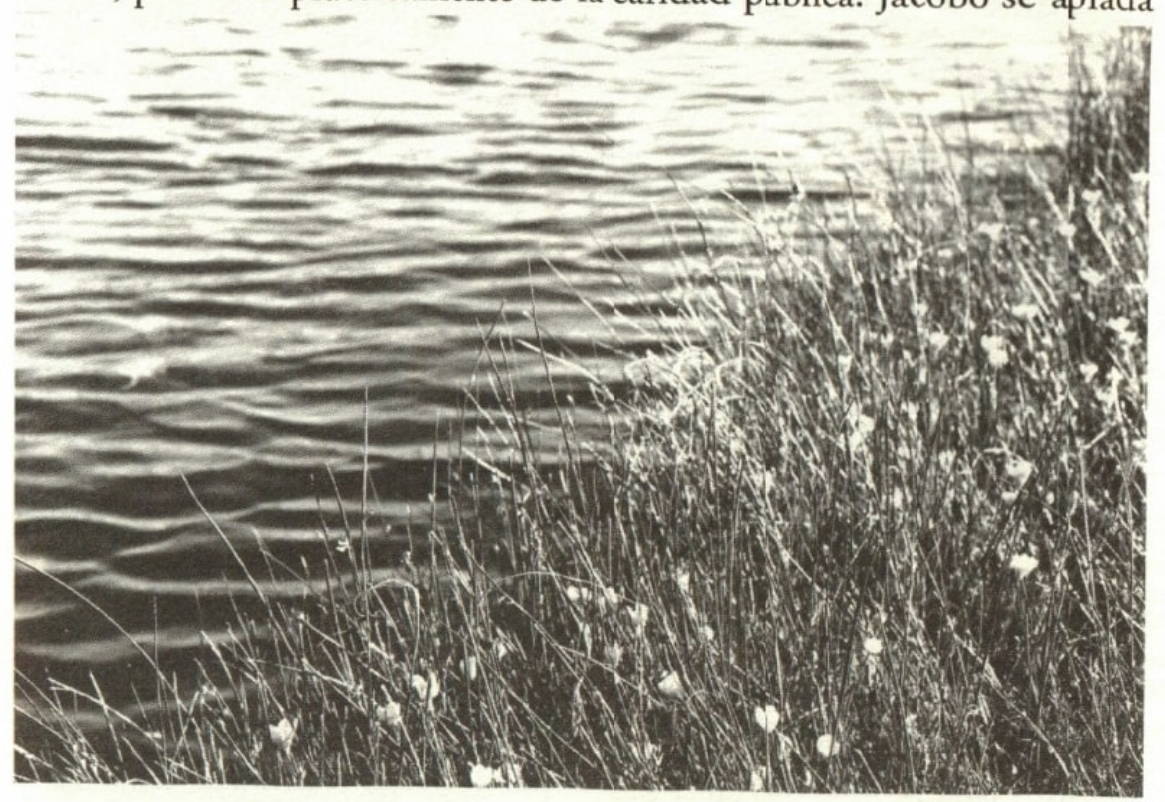

de su mujer. Propone que viajen juntos a la Costa Oeste. En aquella región vive Abraham Pliniak, el hermano espiritual, quien más de una vez le ha

FIGURA 3.

Escritura fotográfica

Fuente: Jacobo el mutante en Obra reunida (283)

Hay una foto en particular en la que podemos distinguir tanto el agua como el pasto, es decir, los elementos de la fotografía. Sin embargo, el ángulo, el encuadre, el blanco y negro, y el tratamiento del contraste sugieren que los dos elementos han entablado, visualmente, una relación de continuidad. Una vez identificada esa relación de continuidad, es posible hacer una experiencia visual: los elementos comienzan a perder sus límites y lo que queda de ellos es el juego de texturas, una suerte de oposición no ya entre los elementos (el mineral y el vegetal), sino entre el resto material de una impresión sensible: a la izquierda, la textura es apaisada, medianamente armónica; a la derecha, la textura es vertical, más o menos caótica. La naturaleza, vuelta sinécdoque de lo sensible, es presentada como una suerte de trazado fotográfico: ahí, también, es una escritura.

Imaginemos que a una hoja blanca la hubiéramos cubierto de tinta y que, con algún tipo de elemento con punta, hubiéramos comenzado a realizar una serie de trazos. El experimento nos recuerda a la técnica tradicional de escritura que sobre el papel blanco esparce la tinta, solo que este procedimiento la ha invertido: el trazado genera, en realidad, un vacío en la tinta que acaba por descubrir un fondo blanco. Las imágenes de Jacobo el mutante sugieren tal figura: la fotografía se transforma en una escritura, invertida, claro está. De ella queda lo más crudo de una impresión sensible (una diferencia de intensidad, la tensión entre la luz y su ausencia); y ese acabado no puede parar de sugerirnos, simultáneamente, esa otra tensión que nos remite a la materialidad de la escritura en la que el papel y la tinta son, antes que nada, texturas que entablan una relación visual. La escritura se vuelve, entonces, una fotografía invertida. Vale recordar, en este punto, que si de algo "trata” el texto es de una experiencia trans. Es decir, una trans-formación en género, espacio y tiempo.

Es decir, si en la comparación de Shiki Nagaoka y el Jardín de la señora Murakami leíamos la formación de una suerte de bipolaridad entre los nombres y las fotografías en torno a su carácter creativo; podríamos decir que en Jacobo el mutante ese espacio fronterizo se ha instalado, exponiendo no tanto una indiferencia, sino, como diría Didi-Huberman vía Aby Warbug, su con-naturalidad o coalescencia natural (3). Desde esa 
perspectiva, el arte sería algo así como las distintas metamorfosis estéticas que la impresión de lo sensible deja en nosotros: el resto de un toque de lo real en el conjunto nervioso, una huella dactilar en la subjetividad. Recientemente, en El libro uruguayo de los muertos, esta imagen del arte-literatura aparece ejemplarmente conceptualizada:

Creo que ya encontré una suerte de ruta. Al menos, por ahora, solo fotográfica [...]. Ahora, con la cámara, la palabra hecha imagen en su negativo, en su alma, en el espacio mínimo donde la foto no es todavía foto porque no ha sido revelada y, sin embargo, la toma ya ha sido hecha. Lo fotografiado bajo estas circunstancias se convierte en el nuevo abismo que se me presenta delante. De esta manera, imaginando que una obra nunca acaba de ser porque no es más que una suerte de remembranza, me parece que voy a ir recorriendo mis propios libros. Buscaré, en el cerebro y en el corazón, que transiten solo a través del ojo que mira el instante. En una suerte de toma en espera, a la cual solo yo pueda darle cierta forma. (21)

En ese entre-lugar del negativo fotográfico, donde la foto "no ha sido revelada", pero la toma "ya ha sido hecha”, la palabra alcanza un punto de coalescencia con la imagen. Pues entre lo registrado (la toma) y lo producido (el revelado) se abre un abismo al que "solo yo puedo darle forma". Ese "yo", lo sabemos, no designa a persona alguna, sino "una ruta" (posición o función) en la que cualquier sujeto podría encontrarse: en "la cueva de lo propio pero abierto asimismo a la indefensión de la vida". Lo que llamamos extimidad, un "sitioguión, ni plenamente mimético, ni totalmente mágico, sino ético” (Antelo, Crítica 28). Allí se sitúa y contacta lo que vacila entre lo interior y lo exterior: lo real.

Desde ese sitio-guión, se visualiza, más que un giro intimista, una suerte de inclinación por lo íntimo: la remembranza de la "propia obra" a través "del ojo que mira el instante". Ejemplar al respecto es Perros héroes. Tratado sobre el futuro de América Latina visto a través de un hombre inmóvil y sus treinta Pastor Belga Malinois (2003).

En ese libro se reúnen en mayor o menor medida los elementos que hemos venido trabajando e, incluso, muchos más que la crítica ya ha abordado. Pero lo que nos interesa resaltar aquí es la figura que bordea sus pre-textos creativos.

En Perros héroes se relata el encuentro entre el "hombre inmóvil", personaje del libro, y un

niño que decía haber escrito un libro sobre perros de vidas heroicas. Aquel niño lo había ilustrado con figuras recortadas, parecidas a las que se multiplicaban alrededor de su cama. El niño escritor llegó de visita al pabellón durante el mes de octubre de 1967. (Obra reunida 362)

Esa vez, el hombre-inmóvil pidió una máquina de escribir a las enfermeras de la institución en la que se encontraba porque "mientas miraba las láminas que ellas le recortaban" le surgió el deseo de "escribir una serie de historias" como hacía este niño (Obra reunida 364).

Dos años más tarde, en un texto que lleva por título el nombre de una máquina de escribir, leemos: "Quizás todo comenzó cuando tenía diez años. De buenas a primeras se me ocurrió hacer un libro de perros" (Obra reunida 501). El ejemplar reunía "historias de perros" acompañadas de "ilustraciones" y de "recortes de diarios y revistas". Pero, a excepción del resto de la familia, su abuela fue "la única persona" que se dio cuenta de "la verdadera situación" y preservó el ejemplar "en el fondo de su ropero". Cuando ella murió, dice Bellatin, la vergüenza le impidió solicitarlo: "Nunca más lo volví a ver" (Obra reunida 501). Sin embargo, ese libro guardado en el closet de la abuela es lo que, paradójicamente, el autor dice "retomar" a la hora de escribir Perros héroes (Aguilar Sosa, "Escribo").

En otra entrevista, interrogado por la relación realidad-ficción que la incorporación de fotografías evidencia, Bellatin responde que el libro no fue "un producto puro de la imaginación", sino una "especie de crónica de un personaje de la ciudad recientemente fallecido" que una vez contactó con el fin de comprarle un perro. El ejerció fue, desde esta óptica, un "acto de reconocimiento" que se produjo "un año y medio después" de su primera visita. En ese tiempo, Bellatin había escrito el libro "casi sin pensar" y decidió regresar a la casa constatando con asombro cómo su libro de ficción había "retratado la realidad" con detalle. Volví, dice Bellatin, "con una cámara de fotos e hice algunas imágenes al azar. Cuando las vi me di cuenta de que la 
ficción que expresaban las imágenes era perfecta. Decidí por eso incluirlas en el libro y hacerlas pasar como instalaciones" (Magagna).

Como vemos, las interferencias entre la ficción de Perros héroes, la de Underwood portátil y las entrevistas de Bellatin conforman un imaginario pre/post textual complejo y anacrónico. Se trata del archivo agujereado, desecho, pero no en el sentido del montaje (como es el caso de Efecto invernadero), sino de la imposibilidad de acceder a esa archivación inscripta en algún soporte: si el escritor vuelve al archivo es por la vía de la imagen, en este caso, la remembranza y la fotografía. Sergio Chejfec, a través de otro recorrido, percibe algo similar:

Estos párrafos aislados le han dado algún sentido a algo que ya no vemos y que probablemente se ha disuelto; pero esa presencia retorna mencionada, como la única forma de registrar su antigua entidad [...]. Rastros de objetos, marcas de lo que existió, presencias cuyos tiempos distintos han coincidido en un mismo sitio [...] para ser contemplados como prueba. Quizá el subtitulo no postule el futuro sino bajo la forma como se verá nuestro presente cuando le toque ser pasado.

Pero las "pruebas" o "documentos", como el negativo fotográfico, no vienen a comprobar más que el afán por instalar la escritura en ese instante infinito que se abre entre el registro (la toma) y la producción (el revelado). O, como ya lo expusimos, la existencia de lo in-existente. Hay una foto en la que sobre una jaula se ven figuras de perros, folletos, revistas, fotografías y objetos (figura 4). La reunión azarosa, fotografiada por Bellatin, conjura un sentido arrasador: allí, en esa experiencia de collage y de montaje el libro iniciático es recobrado, no dentro, sino sobre ese otro closet que puede ser una jaula. Si en la ficción el niño Bellatin se contactó con el niño Inmóvil, allí está la foto para probarlo.

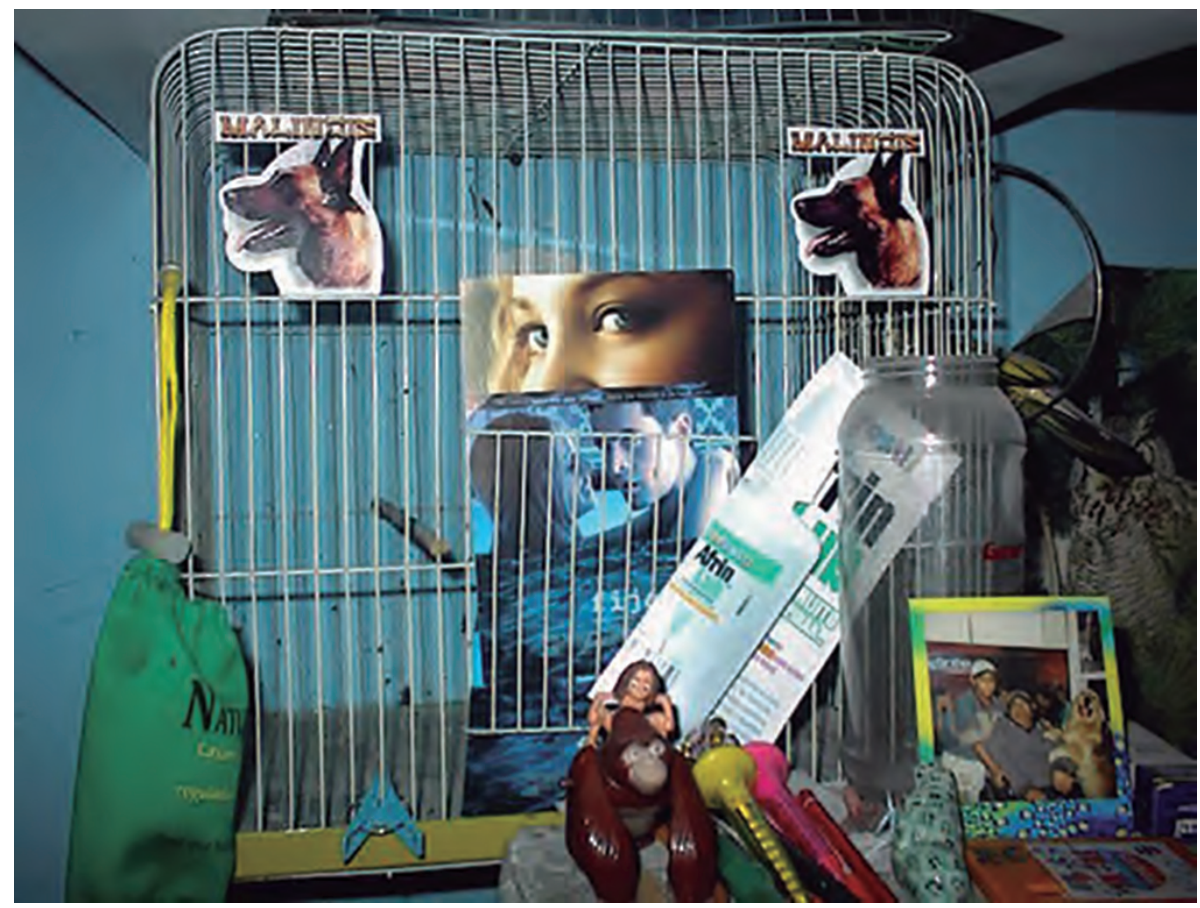

FIGURA 4.

El libro recobrado

Fuente: Pérros héroes en Obra reunida (371)

Así vista la cosa, el escritor se convierte en el arqueólogo de un espacio agujereado. Y, de ese modo, todos esos closets a los que "solo yo" puedo dar forma se transforman en una suerte de, ya lo dijimos, espacio cualquiera. O, en los términos del autor, "jardín público": una puesta en común de la experiencia estética. Y la imagen —sea fotográfica, lingüística, mental o sonora - se presenta como un modo de la materia dotado de plena realidad (Álvarez Asiáin 160). Eso, y no otra cosa, es lo que el autor llama "escritura”. En tales términos, convendría comprender las performances o los proyectos que lo posicionaron en el campo expandido e inespecífico de las artes contemporáneas, pero que, según sus términos, no son más que "sucesos de escritura". Es decir, todas esas 
“acciones plásticas” que "consisten en escribir sin utilizar los métodos clásicos de escritor como por ejemplo las palabras” (Bellatin, Disecado 19).

\section{Instituciones, escritura, vida}

Entre el 2000 y el 2001, Bellatin funda una Escuela Dinámica de Escritores, lo que parece ser otra de las interrogaciones de este momento de su producción que venimos intentando precisar. Ya el nombre, como puede observarse, es sugestivo. Designa una escuela y no un taller o una academia. Etiquetas que, se hipotetiza, disimulan la jerarquía de la enseñanza y lo escolarizable de la "literatura", reemplazándola por una dudosa cuestión colaborativa y práctica junto con un falso discurso de lo "in-enseñable”. Sin embargo, esto último no es una corrección política para la Escuela, sino una premisa fundamental: sostener que la escritura (y no la literatura) pertenece a un orden que nada tiene que ver con lo enseñable, y practicarlo. Lo que significa no solo que no se puede ni debe enseñar a escribir, sino que, en realidad, la escritura no enseña absolutamente nada.

Lo que nos conduce al siguiente concepto: esta institución es dinámica. Lo que quiere decir que carece de todo programa curricular, no hay cursos ni profesores regulares, mucho menos "clínica de obra" ni, por supuesto, escritura. Esa es la otra "regla de oro": está prohibido escribir. Es decir que, en las sesiones de la Escuela Dinámica —en general muy breves-, los alumnos tienen reglamentariamente prohibido someter a sus maestros transitorios a la lectura o evaluación de sus escritos.

Semejante proyecto se instala, como el páramo de Jacobo el mutante, en "las fronteras, donde de algún modo se desdibuja aquello que conocemos como literatura y se forma un cuerpo en el cual el ejercicio de la escritura toma la categoría de práctica artística" (Bellatin, El arte de enseñar a escribir 9 ). De modo que, una vez prohibida la escritura para los discípulos dentro de los marcos de la escuela, la única práctica lícita es el contacto con la imagen a través de otras artes y prácticas. En palabras de Bellatin: "Despejar, acampar, curar" (Carelly Lynch, "Los secretos").

Según Daniel Link - maestro que transitó la institución -, la experiencia de la escuela dirime la enseñanza de la escritura y la formación del escritor en el "orden de lo imaginario", colocando la institución "bajo el signo de la conversación socrática”. Así las cosas, lo primero que un escritor debería aprender "es volverse irreconocible a sí mismo, es encontrar en su lugar un espacio vacío, precisamente eso que lo transforma (que podría llegar a transformarlo) en una 'forma-de-vida" ("El escritor" 1). Es evidente que esta "operación" se encuentra desarrollada "en todos y cada uno de sus libros" ("El escritor" 2). Pero, además del vacío (de la escritura y de sí), lo que se repite también son sus formas de planteamiento: la paradoja y la bipolaridad. No sería precipitado, entonces, afirmar que estamos frente a un momento de inflexión en la producción de Bellatin en el que tales operaciones, como sus formulaciones, además de intensificarse, adquieren una orientación específica por la vía regia de la imagen que, como él mismo lo sostiene, implicará "volver a mirar" su obra.

Tomemos por caso el Congreso de Dobles de Escritores, no menos polémico que la escuela, realizado entre el 19 de septiembre y el 1 de noviembre de 2003, en el Instituto de México en París. Como se puede leer en diversos artículos periodísticos, científicos y en entrevistas, la particularidad de este encuentro de escritores fue que ellos mismos se encontraron ausentes. Es decir que fue la ausencia conjurada como negación de toda esencia lo que estuvo presente en cada aspecto de la obra. Explica Jorge Volpi: "Una exposición que no es una exposición, organizada por un curador que no es un curador, un novelista que no es un novelista, en la que invita a otros tantos escritores que no estarán presentes" (Escritores 226; resaltados propios). Los invitados fueron Margo Glantz, Salvador Elizondo, Sergio Pitol y José Agustín.

Ese vaciado, explica Bellatin, tuvo un propósito bien sencillo: trasladar "solo ideas" más allá de un "contexto" o "circunstancia" como puede ser la presencia del autor. Sin embargo, lejos estuvo este nocurador de resucitar al autor para volver a matarlo, puesto que, aunque ausente, sus palabras (sus textos) eran 
pronunciadas iy gestualizadas! por dobles ("representantes", dice Bellatin), "quienes durante seis meses fueron entrenados - por decirlo de alguna manera- en diez temas por los propios autores” (Escritores 4). Ellos fueron: Gabriel Martínez, Cecilia Vázquez, Marcela Sánchez Mota y Héctor Bourges Valles.

Estas precisiones bien conocidas por la crítica a veces obvian un detalle crucial: la dinámica de la performance. El congreso sucedió en una sala donde se dispusieron cuatro pequeñas mesas, dos sillas por mesa, un micrófono y un "menú literario" con los temas creados por los escritores. Por lo tanto, a la vez que los textos se ofrecían "en forma personal" (cara a cara), las voces de los representantes (ampliadas por el micrófono) podían oírse, simultáneamente, en toda la sala (Escritores 4). Recordemos que se trata de escritores de México en París, por eso, a las voces de este coro hay que sumarle la de "un traductor que trata de atender al tiempo las cuatro mesas". Así presentado, el congreso no solo cuestiona cualquier objetividad, sino fundamentalmente "el sentido temporal de lo literario, casi siempre atado a una suerte de pesado", pues la "mediación" estaría a la sazón de insertar tal experiencia "en lo imprevisto de un futuro" (Escritores 6).

Del congreso no hay registros fílmicos, pero sí un libro bilingüe: Escritores duplicados / Doubles d'écrivains. Allí, además de los "temas" desarrollados por cada autor, un prólogo de Bellatin y un epílogo de Volpi que precisan ese y otros experimentos, se nos muestran las fotografías del proceso de "entrenamiento". Esa misma mostración del artificio, que en el libro otorga un cariz de seriedad a la maliciosa e irónica intervención, fue exhibida originariamente en el congreso. La mayoría de los dobles traspasaban los géneros y/o las edades. Mientras que las performances, paulatinamente, se fueron vaciando: "La primera semana hubo dobles en escena. Durante la segunda semana se proyectaron videos de los dobles recitando los textos. Luego, solo imágenes" (Link, Suturas 263).

Otro detalle que en este contexto se vuelve insoslayable es la edición del libro. Cuando el fondo es blanco, las letras son negras. Cuando el fondo es negro, las letras son blancas. En la portada el libro no tiene título, en su lugar se ven los nombres de los invitados y, en el inferior, se lee "Un proyecto / un projet de Mario Bellatin" junto a una foto de su rostro. En la portada no hay sinopsis, sino cuatro objetos que se asocian con los escritores por medio de sus nombres. Si abrimos el libro, la "portadilla" que separa a un escritor de otro es su nombre a la derecha y, a la izquierda, el duplicado del nombre, pero invertido, como visto a través de un espejo. Luego, vienen los diez textos. Después, las fotografías son tiras de fotos minúsculas que se van agrandando a medida que pasan las semanas (uno, dos, tres y cuatro) hasta que una sola foto ocupa dos páginas del libro. Entonces, se aprecia lo obvio, el libro en sí es una acción plástica que homenajea el negativo fotográfico, esa suerte de camino que más arriba analizábamos.

La conclusión de Bellatin, recuerda Link, "sobre los efectos de aquella experiencia pura de presente es tajante: 'no pasó nada” (Suturas 263). Sin embargo, la experiencia no puede ser más promisoria. Pues el congreso, bien mirado, es un canto al carácter paradojal del autor: "El mismo gesto, que niega toda relevancia a la identidad del autor, afirma sin embargo su irreductible necesidad" (Agamben, Profanaciones 84). No es que el autor haya muerto, precisa Agamben, "sino que a él le corresponde el papel de muerto en el juego de la escritura” (Profanaciones 85). En ese teatrillo, el arte no puede aparecer, sino bajo una máscara mortuoria y con el artista en el lugar del muerto (Link, Suturas 263), es decir, como imagen: nuestra forma se torna en imagen cuando es capaz de vivir más allá de nosotros (Coccia 22).

En ese sentido, la intervención de Bellatin indagaba sobre la relación entre literatura e imagen, vida y muerte, reproducción y descreación. Poniendo estas polaridades en un lugar íntimo y extraño a la vez, cara a cara pero en altoparlante, múltiple pero simultáneo, bilingüe pero bajo el auxilio de una traducción que de igual modo no podrá responder cabalmente a demanda alguna. Y el escritor, en la falla de sentido que esa cámara de ecos supone, aparece como una forma-de-vida mutante, una criatura singular pero clonada: lo múltiple entramado en ese continuum sensible llamado escritura.

Esa experiencia bipolar de los medios o de la medialidad adquirirá una nueva formulación en Condición de las flores: la contemplación, más que la lectura de los textos, ha llevado a descubrir que "la escritura no es más que una sola” (10). ${ }^{10}$ Semejante postulación pone en relación todas las vidas y ninguna, todos los textos y 
ninguno, y propone a la vez un lugar pleno de sentido, así como uno completamente vaciado del mismo. Ese desasosiego por el sentido y el sin-sentido, por lo visible y lo invisible, es, si no me equivoco, lo que estuvimos explorando. En definitiva, se trata de una pregunta bioestética por lo sensible, que ejemplarmente podemos leer en Jacobo el mutante: "No existe nadie" que "no conozca" la frontera, sin embargo,

tanto en los días de verano como de invierno se puede ver en las noches la caseta iluminada con una débil luz amarilla —que parece acercarse y alejarse en forma constante-, lo que transforma la frontera en un punto de engañosa existencia. (Obra reunida 279)

\section{Conclusión (o coda)}

Si algo se quiere señalar con este recorrido, de apariencia rapsódica, es que la irrupción de las fotografías en los libros de Bellatin coincide no solo con la intensificación de su "falsa retórica" que leímos de diversas formas (los imaginarios exotistas y demás), sino también con una preocupación por el estatuto literario, especialmente en lo que respecta a la imagen del autor-escritor. Por ejemplo, El jardín de la señora Murakami pone al autor en el lugar de la traducción; Jacobo el mutante lo pone en las fronteras-mutaciones; Shiki Nagaoka hace del alter-ego y la propia literatura el lugar del autor favorito, es decir, del otro fantaseado; en Perros héroes, el autor es un niño o el otro; en el Congreso de Dobles de Escritores, se pone al autor en el lugar del muerto, y Underwoodportátil. Modelo 1915 resume, por medio de la máquina de escribir y su modelo, una suerte de ars poetica de todo esto. Los ejemplos no son azarosos, sino que pretenden proponer una hipótesis: del 2000 al 2005 (la fecha de tales textos, respectivamente) se produjo en la obra de Bellatin una exploración y una insistente reformulación de las preguntas generadas por la imagen de la literatura.

Por otro lado, en la medida que la escritura de Bellatin trabaja sobre el estatuto perceptivo-sensitivo de los lenguajes, los cuerpos y los sujetos, acaba formulándose una interrogación por lo sensible, que se superpone con la anterior pregunta y la expande. Es en esa perspectiva que la exploración de la relación entre imagen y literatura se volvió ineludible, llevando a la crítica y al mismo Bellatin a situar sus obras y proyectos en relación con otras artes y prácticas e, incluso, con otras formas visuales y epistémicas, como el imaginario de un niño de diez años.

Por eso, en el momento en el que Bellatin ingresa fotografías y dibujos en sus libros, a la vez que realiza acciones o intervenciones, como el Congreso de Dobles de Escritores o La Escuela Dinámica de Escritores, estas dos interrogaciones bien distinguibles entran en resonancia de modo explícito e ineludible. Es decir, la imagen fotográfica o la imagen del autor-escritor aparece en la escena "literaria" (el libro, el manuscrito, el documento, el congreso, el teatrillo, la escuela) para experimentar e interrogar in situ tanto lo sensible como la imagen de la literatura. Ante tales experimentos, las lecturas e hipótesis que hemos planteado tuvieron por objetivo intentar precisar tanto sus condiciones como sus presuntos resultados. Sin el afán de establecer una taxonomía, este momento creativo de Bellatin parece marcar un punto de inflexión en su obra.

\section{Bibliografía}

Agamben, Giorgio. Profanaciones. Adriana Hidalgo, 2005.

Agamben, Giorgio. Signatura rerum. Sobre el método. Anagrama, 2010.

Aguilar Sosa, Yanet. "Escribo para saber quién soy: Bellatin". El universal, 29 de mayo de 2007, https://archivo.eluniv ersal.com.mx/cultura/52757.html. Consultado el 16 de febrero de 2016.

Álvarez Asiáin, Enrique. Guilles Deleuze y el problema de la imagen. De la imagen del pensamiento al pensamiento de la imagen. 2011. Universidad de Buenos Aires, tesis doctoral.

Antelo, Raúl. Crítica acéfala. Grumo, 2008.

Antelo, Raúl. "El tiempo de una imagen, o el tiempo-con". Cuadernos de literatura, vol. 19, n. ${ }^{0}$ 38, 2005, pp. 376-399. 
Barthes, Roland. La cámara lúcida. Paidós, 1990.

Bellatin, Mario. Condición de las flores. Entropía, 2008.

Bellatin, Mario. Disecado. Sexto Piso, 2011.

Bellatin, Mario. "Dos narraciones clásicas sobre el tema de la nariz". Shiki Nagaoka: una nariz de ficción. Pontificia Universidad Católica del Perú, 2002.

Bellatin, Mario. El arte de enseñar a escribir. Fondo de Cultura Económica, 2006.

Bellatin, Mario. El libro uruguayo de los muertos. Criatura Editora, 2013.

Bellatin, Mario. Escritores duplicados / Doubles d'écrivains: narrateurs mexicains à Paris. Landucci Editores, 2004.

Bellatin, Mario. Obra reunida. Alfaguara, 2005.

Benjamin, Walter. "Pequeña historia de la fotografía". Discursos ininterrumpidos I. Filosofía del arte y de la historia. Taurus, 1989.

Carelly Lynch, Guido. "Los secretos de la Escuela de Escritura de Mario Bellatin”. Revista N, 17 de noviembre de 2008.

Coccia, Emanuele. A vida sensivel. Cultura e Barbárie, 2010.

Conde, Laura. "Mario Bellatin: una escritura tridimensional". VI Jornadas Internacionales de Filología y Lingüistica, 2013, Facultad de Humanidades y Ciencias de la Educación (UNLP), La Plata.

Contreras, Sandra. Las vueltas de Cesar Aira. Beatriz Viterbo, 2002.

Chejfec, Sergio. “Cuados de una instalación”. Bazar Americano, n. ${ }^{\circ} 14$, agosto-noviembre de 2004, https://tinyurl.co $\mathrm{m} /$ yau7f4pp. Consultado el 12 de febrero de 2016.

De Duve, Thierry. “Sintoma e intuição”. Novos estudos, n. ${ }^{\circ}$ 79, noviembre de 2007, pp. 210-227.

Deleuze, Gilles. La imagen-movimiento. Estudios sobre cine I. Paidós, 1984.

Deleuze, Gilles, y Félix Guattari. ¿Qué es la filosofia? Anagrama, 1997.

Díaz, Marcelo. "Hechos misteriosos". Bazar Americano, n. ${ }^{\circ} 22$, abril-julio de 2007, http://www.bazaramericano.com /resenas.php?cod=136\&pdf=si. Consultado el 12 de febrero de 2016.

Didi-Huberman, Georges, et al. Cuando las imágenes tocan lo real. Círculo de Bellas Artes, 2013.

Echevarren, Roberto. Arte andrógino: estilo versus moda en un siglo corto. Colihue, 1998.

Foster, Hall, et al. Arte desde 1900. Akal, 2006.

Foucault, Michel. Microfísica del poder. La Piqueta Ediciones, 1980.

Freud, Sigmund. "Fetishism”. International Pournal of phycho-Analysis, n. ${ }^{\circ}$ 10, abril de 1928, pp. 161-166.

Lacan, Jacques. Le seminaire. Livre XIV: la logique du fantasme. Inédito, 15-19 de abril de 1967, École Lacanienne de Psychanalyse.

Link, Daniel. "El escritor como 'forma-de-vida". Landa, n.o 0, 2012, pp. 1-6, https://revistalanda.ufsc.br/PDFs/link _landa_0.pdf. Consultado el 12 de febrero de 2016.

Link, Daniel. Fantasmas. Imaginación y sociedad. Eterna Cadencia, 2009.

Link, Daniel. Suturas. Eterna Cadencia, 2015.

Los Asesinos Tímidos. "Entrevista a Mario Bellatin". Agosto de 2008, http://asesinostimidos.blogspot.com/2008/08/ entrevista-mario-bellatn.html. Consultado el 12 de febrero de 2016.

Magagna, Neyra. “Entrevista a Mario Bellatin”. Letras s5, 1 de julio de 2006, http://carlosmsotomayor.blogspot.com/ 2007/01/entrevista-mario-bellatin.html. Consultado el 12 de febrero de 2006.

Nancy, Jean-Luc. Corpus. Métailié, 2000.

Nietzsche, Friedrich. Aurora. Edaf, 1996.

Pardo, José Luis. La regla del juego: sobre la dificultad de aprender filosofía. Galaxia Gutenberg, 2004.

Pauls, Alan. "El problema Bellatin". El interpretador, n. ${ }^{\circ}$ 20, 2005. Consutlado el 20 de septiembre de 2012.

Ruiz, Facundo. "Vitrinas narrativas. Mario Bellatin y el relato fotográfico". Revista de Crítica Literaria Latinoamericana, n. ${ }^{\circ}$ 68, 2008, pp. 201-210, https://as.tufts.edu/romancestudies/rcll/pdfs/68/RUIZ.pdf. 
Sánchez, Matilde. "Cómo adiestrar a la literatura”. Revista Ñ, 27 de ago del 2005.

Walker, Carlos. "Mario Bellatin: imágenes literárias”. II Congreso Internacional “Cuestiones Críticas”, 2009, Rosario, Universidad Nacional de Rosario.

\section{Notas}

\section{* Artículo de investigación}

[1] Sin embargo, un pretexto de Poeta ciego, libro publicado en 1998, fue adaptado al teatro por Gustavo Frigerio en 1993 bajo el título Black-out (Los cadáveres valen menos que el estiércol). Si bien este no solo se detiene en el ingreso de fotografías en los libros de Bellatin, sino también en otros modos de aparición de la imagen, como las performances, no incluiremos a Black-out en este recorrido. Esto obedece, en principio, a dos razones: en primer lugar, a diferencia del congreso, la escuela o la representación teatral de Salón de Belleza, Black-out es un elemento-obra que la escritura de Bellatin no ha incorporado a la ficción de manera directa, es decir, por su nombre propio; y, en segundo lugar, el momento de aparición de la versión teatral de Black-out en su obra temprana es singular y asistemático, por lo que merece una atención especial. Para un análisis genetista de los archivos que contiene Blackout, véase "Mario Bellatin: una escritura tridimensional" de Laura Conde.

[2] La analogía, explica Agamben, "se opone al principio dicotómico que domina la lógica occidental", pues "siempre hace valer su tertium datur, su obstinado 'ni A ni B'” ( Signatura 25-26). La analogía interviene, entonces, para transformar las dicotomías lógicas (particular-universal, forma-contenido, legalidad-ejemplaridad) "en un campo de fuerzas recorrido por tensiones polares, en el cual, del mismo modo en que ocurre en un campo electromagnético, estas pierden su identidad sustancial” (26). Así las cosas, el sentido y el modo en los que se da el tercero en la analogía bipolar es a través de "la desidentificación y la neutralización de los dos primeros, que se vuelven entonces indiscernibles" y necesariamente “indecible[s]”. Esta es la condición paradigmática: el "valer para todos" del ejemplo, como "su ser un caso singular entre los otros" (26).

[3] En Efecto invernadero (1992), el texto empieza y termina citando los “cuadernos de ejercicios" de Antonio, así como también tiene por epígrafe el fragmento de un poema de Cesar Moro; en Canon perpetuo (1993), los relatos del médico son impulsados por el recuerdo del relato de un niño en su consultorio; en Salón de Belleza (1994), el relato del moridero se intercala con los relatos sexuales del estilista; Poeta ciego (1998) cuenta con un "cuadernillo de las cosas difíciles de explicar", así como también con un conjunto de tratados donde se encuentran los principios de la Organización, etc. Como puede observarse, si bien estos relatos se han presentado como libros, cuadernos y escrituras, nunca habían tenido tanto que ver, hasta este momento de la producción de Bellatin, con la literatura y sus instituciones, especialmente con formas tales como la crítica, la traducción, la biografía y el comentario. De este momento, además de Shiki Nagaoka, también participarían otros textos, especialmente, El jardin de la señora Murakami (2000) y Jacobo el mutante (2002).

[4] Tenemos, por un lado, explica Benjamin, los "clichés" del reportaje, donde las fotografías "no tienen otro efecto que el de asociarse en el espectador a indicaciones lingüísticas". De igual modo, se "empequeñece” la cámara en el otro polo: al fijar imágenes "cuyo shock suspende en quien las contempla el mecanismo de asosicación". Por eso, "debe intervenir la leyenda, que incorpora a la fotografía en la literaturización de todas las relaciones de la vida, y sin la cual toda construcción fotográfica se queda en aproximaciones" (82). Así, Bejamin se interroga: ¿un fotógrafo que no lee sus propias imágenes, no es menos analfabeto que aquel que ignora la fotografía?, ¿no es la leyenda, entonces, uno de los componentes esenciales de las fotos?

[5] El "plano de inmanencia" es un todo no fragmentado en el que estamos "ahora ya y siempre", no un concepto pensado ni pensable, sino su límite, lo preconceptual: una comprensión intuitiva vinculada a la experimentación (Deleuze y Guattari 40-42). En otras palabras, "expresa la manera problemática en la cual el mundo afecta al pensador antes de que aparezcan los conceptos que le dan la forma de lo pensable" (Álvarez Asiaín 82). Afrontar la inmanencia implica restituir el verdadero movimiento entre lo conceptualizado y el límite caótico que tiene por plano: es alcanzar el elemento de lo paradójico en su sentido transcendente. Lo infotografiable es aquello que solo puede ser fotografiado cuando el sentido común ya no está allí para limitar lo sensible y los órganos de la percepción se han vuelto metafísicos.

[6] Daniel Link propone comparar el mingitorio duchampiano con el "Hombre de Vitrubio" de Leonardo Da Vinci, en el que el ombligo es el centro del círculo, mientras que el centro del cuadrado es el sexo, y el "hombre itifálico" de Cesare Cesariano que con "un poco de azar y deformación" hace coincidir las dos figuras y los dos centros (el círculo y el cuadrado, pero el ombligo con el falo que erecto lo señala).

[7] Según Thierry De Duve, la primera recepción de la obra de Duchamp se puede leer en esa clave: como fetichización del objeto artístico a partir de la figura del artista (215-216). 
[8] Explica Agamben en Profanaciones : "Vivir con Genius significa, en este sentido, vivir en la intimidad de un ser extraño, mantenerse constantemente en relación con una zona de no-conocimiento. Pero esta zona de no-conocimiento no es una remoción, no mueve o traslada una experiencia de la conciencia al inconsciente, donde sedimenta como un pasado inquietante, listo para aflorar bajo la forma de síntomas o neurosis. La intimidad con una zona de no-conocimiento es una práctica mística cotidiana, en la cual el Yo, en una suerte de especial, alegre esoterismo, asiste sonriendo a su propia ruina y, ya se trate de la digestión del alimento o la iluminación de la mente, testimonia incrédulo su propia e incesante disolución. Genius es nuestra vida en tanto que no nos pertenece [...]. De aquí la pertinencia y el éxito de operaciones irónicas como las de las vanguardias, en las cuales la presencia de Genius era atestiguada mediante la de-creación, la destrucción de la obra. Pero si solo una obra revocada y deshecha puede ser digna de Genius, si el artista verdaderamente genial es el artista sin obra, el Yo-Duchamp no podrá nunca coincidir con Genius y, en la admiración general, se va de viaje por el mundo como la melancólica prueba de la propia inexistencia, como el tristemente célebre portador de su propia inoperancia” (11-12).

[9] Dice Link en Fantasmas : "Lo indecible, lo necesario de la historia se juega en esos señalamientos. Como recordaba Sarduy 'se sabe de qué esta hecha la masa sumergida de un iceberg mientras que la naturaleza de la masa invisible del universo es un desafío de la imaginación”" (128).

[10] Pero ya en Flores, texto publicado en el 2000, se lee que la "intención inicial" del texto es que "cada capítulo pueda leerse por separado, como si de la contemplación de una flor se tratara” ( Obra reunida 377). Un año más tarde, en La escuela del dolor humano de Sechuán, el texto se abre relatando el método de un "teatrillo étnico": una forma "peculiar de actuación" que comienza, del mismo modo que la cita anterior de Flores, explicándole "al público" el "contenido y la forma de representación que emplearán para llevarlas a cabo” ( Obra reunida 437). Como vemos, además de la típica operación de montaje fragmentario remasterizada por la falsa retórica, ora "sumeria", ora "teatral", lo que se mantiene siempre insistente es la idea "de que la literatura está soportada por lo visual"; el relato (el "contenido y la forma") es "algo que requiere ser visto y después leído; y en este sentido se propone como algo adicional, un suplemento" (Chejfec).

\section{Licencia Creative Commons CC BY 4.0}

Cómo citar este artículo: Cherri, Leo. "Mario Bellatin y la aparición de la imagen”. Cuadernos de Literatura, vol. 24, 2020. https://doi.org/10.11144/Javeriana.cl24.mbai 